J. Amer. Soc. Hort. Sci. 120(2):347-352. 1995.

\title{
Stable Transformation of Gladiolus Using Suspension Cells and Callus
}

\author{
Kathryn Kamo ${ }^{1}$ \\ U.S. Department of Agriculture, Agricultural Research Service, Floral and Nursery Plants Research Unit, \\ Beltsville, MD 20705-2350
}

Alan Blowers, Franzine Smith, and Joyce Van Eck

Sanford Scientific, 877 Marshall Rd, Waterloo, NY 13165

Roger Lawson

U.S. Department of Agriculture, Agricultural Research Service, Floral and Nursery Plants Research Unit, Beltsville, MD 20705-2350

Additional index words. transgenic plants, particle gun, GUS

\begin{abstract}
More than 100 transgenic Gladiolus plants were recovered after particle bombardment of regenerable suspension cells and callus. For transformation, Gladiolus callus and suspension cells were co-bombarded with phosphinothricin acetyltransferase-(PAT) and B- glucuronidase (GUS) -expressing plasmids. Stably transformed calli were selected on medium containing either phosphinothricin (PPT) or bialaphos followed by transfer to a regeneration medium to recover transgenic plants. Stable transformation was confirmed by detection of the PAT gene by DNA gel blot analysis and by enzymatic assays to measure GUS activity. In general, particle bombardment of regenerable suspension cells rather than callus resulted in the largest number of transformants. The rate of co-expression for GUS in PPT-resistant plants was high $(\approx 70 \%)$. Promoters that are typically more efficient in dicotyledonous plants were very active in Gladiolus, a monocotyledonous bulb plant. Establishment of an efficient transformation protocol for Gladiolus will now allow the introduction of transgenes to confer resistance to the viral and fungal pathogens that decrease Gladiolus production.
\end{abstract}

Many of the floral bulb crops-tulips, lilies, hyacinths, narcissus, Crocus, Hemerocallis, Iris- are monocots. Before the development of the particle gun (Klein et al., 1987), monocots had not been readily amenable to transformation using existing techniques. Recently, transgenic plants from several agronomically important monocots-corn, wheat, rice, oat, and sugarcane-have been transformed using particle bombardment of either regenerable suspension cells or callus (Bower and Birch, 1992; Christou et al., 1991; Fromm et al., 1990; Gordon-Kamm et al., 1990; Somers et al., 1992; Vasil et al., 1992; Weeks et al., 1993). Gladiolus is a monocotylcdonous floral bulb crop that ranked fifth in 1993 (U.S. Dept. of Agriculture, 1994) for the number of stems (79,663 million) shipped worldwide. Gladiolus production areas are severely plagued by viral and fungal pathogens; a typical cultivar lasts only several years before it succumbs to disease and is removed from production. Therefore, Gladiolus represents a commercially important floral crop that would benefit tremendously from transgene-mediated crop protection strategies. Although the infection of Gladiolus cormel tissue by Agrobacterium was reported, definitive evidence for transformation by DNA gel blot analysis was not presented and no transgenic plants were recovered (Graves and Goldman, 1987). The goal of this study was to produce a large number of transgenic Gladiolus plants. This is the first report of generation of a large number of transgenic plants of a monocotyledonous floral bulb crop.

Received for publication 14 June 1994. Accepted for publication 24 Oct. 1994. Mention of a trademark, proprietary product, or vendor does not imply its approval to the exclusion of other products or vendors that may also be suitable. We thank Lisa Lee for advice throughout this study. John Sanford for use of his particle gun, and Anne O'Connor and Katerina Serlemitsos for technical assistance. The cost of publishing this paper was defrayed in part by the payment of page charges. Under postal regulations, this paper therefore must be hereby marked advertisement soley to indicate this fact.

'To whom reprint requests should be addressed.

\section{Materials and Methods}

Tissue culture. Regenerablc callus was initiated from either cormel slices or in vitro-grown plantlets of Gladiolus 'Jenny Lee' and 'Peter Pears' (Kamo et al., 1990; Logan and Zettler, 1985) and maintained in vitro for $\approx 4$ to 6 months on MS basal salts medium (Murashige and Skoog, 1962) supplemented with 2\% (w/v) sucrose, $0.2 \%(\mathrm{w} / \mathrm{v})$ Gelrite (Sigma Chemical Co., St. Louis) and the following $\left(\mathrm{mg} \cdot \mathrm{liter}^{-1}\right)$ : glycine, 1.0; thiamine. 1.0: pyridoxine, 0.5: nicotinic acid, 0.5; either 3,6-dichloro-2-methoxybenzoic acid (dicamba), 2.0; $\alpha$ - napthaleneacctic acid (NAA). 10.0. or 2,4dichlorophenoxy acetic acid (2,4-D), 0.5, pH 5.8. All media were autoclave at $121 \mathrm{C} / 18 \mathrm{psi}$. Suspension cells were initiated from the regenerable callus in MS basal salts medium supplemented with the same medium components as for callus, except that Gelrite was omitted. 'Peter Pears' and 'Jenny Lee' suspension cells wet-c cultured in $20 \mathrm{ml}$ of MS basal salts medium supplemented with $2 \mathrm{mg} \cdot \operatorname{liter}^{-1}$ dicamba anti $0.5 \mathrm{mg} \cdot \operatorname{liter}^{-1} 2,4-\mathrm{D}$, respectively. Callus and suspension cells were grown in the dark at $26 \mathrm{C}$. Callus was routinely transferred every month and suspension cells every 7 days at a 1:2 dilution to fresh medium. Suspension ceils were shaken on a gyratory shaker at $120 \mathrm{rpm} / 26 \mathrm{C}$ in the dark.

Plasmid constructs. Plamlid DNA was isolated using alkaline lysis followed by purification from a cesium chloride gradient (Maniatis et al., 1982). Plasmid p35SAc that contains the PAT (phosphinothricin acetyltransferase) gene under control of the CaMV 35S (cauliflower mosaic virus) promoter (P. Eckes, Hoechst Roussell Co., Somerville. N. Y.) was used to transform plant cells. Plasmids used for the evaluation of promoters consisted of the gusA gene under control of the following promoters: Actl (actin) (McElroy et al., 1991; Zhang et al., 1991), CaMV 35S (Odell et al.. 1985), Ubil (ubiquitin) (Christensen et al., 1992), mas2 (mannopine synthase) (Velten et al., 1984), rolD (Leach and Aoyagi. 1991). All constructs that contained the gusA gene under the various promoters were in either pUC or pUC-like vectors to eliminate any 
possible effect from the vector on gene expression. Plasmids used for evaluation of either the Adhl (alcohol dehydrogenase) or Actl first introns were under control of the CaMV $35 \mathrm{~S}$ promoter ((Dennis et al., 1984; McElroy et al., 1991).

Particle gun bombardment. The cells were transformed using the PDS-1000/He system (BioRad, Richmond, Calif.), which is a helium-driven particle accelerator with flying membrane for particle delivery (Sanford et al.. 1991). M10 tungsten particles were coated with plasmid DNA as previously described (Sanford et al., 1993). For all experiments, the gap distance and flying membrane flight distance were set at $1 \mathrm{~cm}$ and the target distance at $12 \mathrm{~cm}$. The suspension cells and callus were bombarded at 8.3 MPa (1200 psi) one and two times per plate, respectively.

Callus selection. One week following particle bombardment. the callus was transferred to MS basal salts medium supplemented with either PPT (phosphinothricin; Hoechst Roussell Co., Somerville. N.J.) or bialaphos (Meiji Seika Kaisha, Tokyo) and either 2 or $1 \mathrm{mg}$-liter dicamba for callus derived from in vitrogrown cormel slices or plantlets, respectively. PPT and bialaphos were added by filter sterilization to autoclaved MS basal salts medium. and the concentration of the selection chemical was based on active ingredient. Callus was transferred every 14 to 21 days to fresh medium during selection containing $6 \mathrm{mg} \cdot \mathrm{liter}^{-1} \mathrm{PPT}$ or bialaphos. When $\approx 70 \%$ of the callus had died, the callus was tl-ansl'erred to regeneration medium, which was MS basal salts

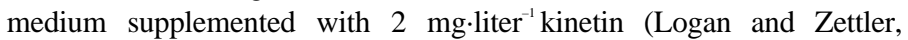
19X5 ) and either- 0, 0.5, or $3.0 \mathrm{mg} \cdot \mathrm{liter}^{-1}$ bialaphos. Regenerating cultures were grown at $26 \mathrm{C}$ under a $16-\mathrm{h}$ photoperiod at $75 \mu \mathrm{E} / \mathrm{m}^{2}$ per sec provided by cool-white fluorescent lights.

Suspension selection. Several methods of selection were used for the suspension cells, and all resulted in transgenic plants. For some bombardments, suspension cells were transferred to MS basal salts medium supplemented with $0.5 \mathrm{mg} \cdot \mathrm{liter}^{-1} 2,4-\mathrm{D}$ and 0.125 M osmoticum $(0.0625 \mathrm{M}$ mannitol and 0.0625 M sorbitol) 2 hours he fore particle bombardment; for other bombardments the osmoticum pretreatment was omitted. Following bombardment, the suspension cells were cultured for one week on solidified MS basal salts medium supplemented with $0.5 \mathrm{mg} \cdot \mathrm{liter}^{-1} 2.4-\mathrm{D}$ and either with or without $0.125 \mathrm{M}$ ostmoticum to allow the cells to recover from bombardment. These cells were then transferred to solidified MS basal salts medium supplemented with 0.5 $\mathrm{mg} \cdot \mathrm{liter}^{-1} 2,4-\mathrm{D}$ and either 1 or $6 \mathrm{mg} \cdot \operatorname{liter}^{-1} \mathrm{PPT}$ or bialaphos. After at least two subcultures onto solidified MS basal salts medium supplemented with 2 or $6 \mathrm{mg} \cdot \mathrm{liter}^{-1}$ bialaphos or PPT, the cells were transferred to regeneration medium supplemented with either $0,0.5$, or $3 \mathrm{mg} \cdot \operatorname{liter}^{-1}$ bialaphos. Alternatively, some of the bombarded cells were cultured 2 weeks in liquid MS basal salts medium supplemented with $0.5 \mathrm{mg} \cdot$ liter-1 2,4$\mathrm{D}$ and $0.1 \mathrm{mg} \cdot$ liter $^{-1}$ bialaphos immediately after bombardment. These cells were then transferred to solidified MS basal salts medium supplemented with $0.5 \mathrm{mg} \cdot$ liter $^{-1} 2,4-\mathrm{D}$ and 1 $\mathrm{mg} \cdot \mathrm{liter}^{-1}$ bialaphos until they were ready for transfer to regeneration medium. All cells on selection media were transferred every 14 to 21 days to fresh media and grown at $26 \mathrm{C}$ in the dark. Cells on regeneration medium were grown in a 16-h light photoperiod at $26 \mathrm{C}$. Shoots that regenerated from the callus and suspension cells were excised and grown on a MS basal salts medium lacking hormone and selection agent where they formed roots.

GUS analysis. The method of Jefferson et al. (1987) was used for histochemical and fluorometric determinations of ß-glucuronidasc (GUS) gene expression in suspension cells and putative, transformed tissues. The specific activity of GUS was measured by fluorometric determination of 4-methylumbelliferone (4-MU). The protein concentrations were determined using the BCA protein assay reagent according to the manufacturer's instructions (Pierce Co., Rockford, Ill.). Transient GUS expression analysis was used to optimize gene delivery into 'Jenny Lee' suspension cells that had been bombarded with gu.sA-containing plasmids. Each experiment consisted of three replicates, and each replicate consisted of two to three plates of suspension cells per treatment. GUS expression was determined $48 \mathrm{~h}$ after particle gun bombardment by adding the substrate 5-bromo-3-chloro-3-indolyl- $\beta$-Dglucuronic acid directly to the filter paper on which the suspension cells were cultured. Following a 16-h incubation of the samples with substrate at $37 \mathrm{C}$, the blue spots were counted. Alternatively, the suspension cells were removed from the filter paper, ground up using mortar and pestle, and then used for the fluorometric determination of specific activity of GUS. Nontransformed plant tissues and suspension cells of 'Jenny Lee' and 'Peter Pears' were used as the negative controls.

DNA analysis. DNA for polymerase chain reaction (PCR) amplification was isolated from fresh leaves grown in vitro essentially according to the method of Dellaporta et al. (1983). PCR amplification was performed using an Eppendorff microcycler. The PAT gene was amplified using the primer sequence: $5^{1}$ GAGAGGAGACCAGTTGAG-3 ' and 5'-TTGGAGGAGCTGGCAAC-3' and the microcycler conditions: $94 \mathrm{C}$ for $3 \mathrm{~min}$ (one cycle), 94C for $1 \mathrm{~min}, 55 \mathrm{C}$ for $1 \mathrm{~min}, 72 \mathrm{C}$ for $2 \mathrm{~min}$ (40 cycles), $72 \mathrm{C}$ for $5 \mathrm{~min}$ (one cycle).

DNA for Southern hybridization was isolated from leaves of in vitro-grown plants using the method of Dellaporta et al. (1983). Undigested DNA $(10 \mu \mathrm{g})$ and DNA digested with either EcoRI or PstI were electrophoresed on a $0.7 \%(w / v)$ agarose (BioRad, Richmond, Calif.) gel in TBE ( $89 \mathrm{~mm}$ Tris-borate, $89 \mathrm{~mm}$ boric acid, 2 mм EDTA, pH 8) buffer at $75 \mathrm{~V}, 50 \mathrm{~mA}$ for $\approx 4 \mathrm{~h}$. Following electrophoresis, the DNA was transferred by capillary movement ova-night to Nytran nylon membrane (Schleicher and Schuell, Keene, N. Y.) (Maniatis et al., 1982). The probe used for hybridization was p35SAc digested with Sall followed by gel purification and labeled by random primer $\left[\alpha-{ }^{32} \mathrm{P}\right]$ dCTP using the Megaprime

Table 1. Comparison of gene promoter activities in suspension cells of Gladiolus 'Jenny Lee'.

\begin{tabular}{lccc}
\hline Promoter & $\begin{array}{c}\text { Gene } \\
\text { source }\end{array}$ & $\begin{array}{c}\text { GUS specific activity } \\
\text { (pmoles }\end{array}$ & $\begin{array}{c}\text { Relative GUS } \\
\text { expression }^{\text {y }}\end{array}$ \\
\hline $35 \mathrm{~S}$ & CaMV & 92 & 1.00 \\
mas 2 & Agrobacterium & 185 & 2.01 \\
rolD & Agrobacterium & 99 & 1.08 \\
Act 1 & Rice & 20 & 0.22 \\
Ubi 1 & Maize & 28 & 0.30
\end{tabular}

${ }^{\bar{z}}$ GUS expression was measured $48 \mathrm{~h}$ after particle gun bombardment of the cells. Values represent the mean of three bombardments (replicates).

'Values represnt relative GUS expression, where $35 \mathrm{~S}-\mathrm{GUS}$ is set at 1.00 . 
Kit (Amersham, Arlington Heights, Ill.). Blots were incubated in prehybridization buffer for $2 \mathrm{~h}$ at $42 \mathrm{C}$ followed by hybridization buffer and probe at $60 \mathrm{C}$ for $16 \mathrm{~h}$ (Maniatis et al., 1982). Three washes in $6 \mathrm{x}$ SSC, $1 \%$ SDS for $5 \mathrm{~min}$ each at 26C, two washes in 1x SSC, $1 \%$ SDS for 1 min each at 65C, and two washes in 2x SSC for $5 \mathrm{~min}$ each at $26 \mathrm{C}$ were done before exposure of the blot at $70 \mathrm{C}$ with an intensifying screen.

\section{Results and Discussion}

Transient GUS gene expression analysis. Initially two promoters, the 35S RNA promoter from cauliflower mosaic virus (CaMV) and the actin 1 (Act1) promoter from rice, fused to gusA were analyzed. The $35 \mathrm{~S}$ and Act1 promoters have been previously demonstrated to direct high levels of gene expression in transformed dicots and monocots, respectively (McElroy et al., 1990; Zhang et al., 1991). We expected that GUS expression in Gladiolus would be highest from the Actl promoter since this promoter is most active in monocots while the CaMV $35 \mathrm{~S}$ promoter is relatively inactive in monocots. Surprisingly, transient GUS expression levels in bombarded Gladiolus cells were nearly 5-fold higher from the CaMV 35S, promoter than from the Actl promoter (Table 1).

Three additional promoters were evaluated: mas 2 and rolD from Agrobacterium and ubiquitin Ubil from maize. From previous reports, the mas 2 and rolD promoters would be expected to be most active in dicots whereas the Ubil promoter would be expected to be most efficient in monocots (Christensen et al., 1992; Cornejo et al., 1993; Leach and Aoyagi, 1991; Velten et al., 1984). GUS expression in Gladiolus was highest from the three dicot- preferred promoters: mas2, rolD, and 35S. We observed that GUS expression from the most efficient promoter, mas2, was 7-fold and 9-fold higher than the Ubil and Actl promoters, respectively.

Next we looked at the effect that the presence of monocot introns might have on GUS expression levels since the Ubil and Act1 promoter-containing fragments used here also contain an intron in their untranslated leader region (Fig. 1). It is well established that addition of an intron such as the first introns from the maize $A d h 1$ and rice $A c t 1$ genes to the primary transcript can dramatically increase gene expression levels in transformed monocots (McElroy et al., 1991). For example, GUS expression in transformed maize cells increased 6- and 60-fold when the Act1 and Adh1 first introns, respectively, were added to a $35 \mathrm{~S}-$ gusA chimeric gene. In contrast to maize, GUS expression was reduced 1.25- and 3-fold in Gladiolus when the Adh1 and Act1 first introns, respectively, were added to a $35 \mathrm{~S}-$ gusA chimeric gene (data not shown). Results similar to those with Gladiolus were found when petunia was bombarded with the exact same intron-containing plasmids (data not shown). These results clearly indicated that GUS expression was not stimulated in Gladiolus cells with the addition of monocot introns to the gusA transcript. This observation suggested that splicing of monocot introns may be relatively inefficient in Gladiolus, a nongraminaceous monocot, as it is in dicots such as petunia. Alternatively, stimulation in gene expression by introns may be a feature that is generally limited to graminaceous monocots like maize and rice.

Results similar to those obtained with Gladiolus were also observed with orchid, another nongraminaceous monocot (data not shown). The $35 \mathrm{~S}$ promoter was most active in bombarded
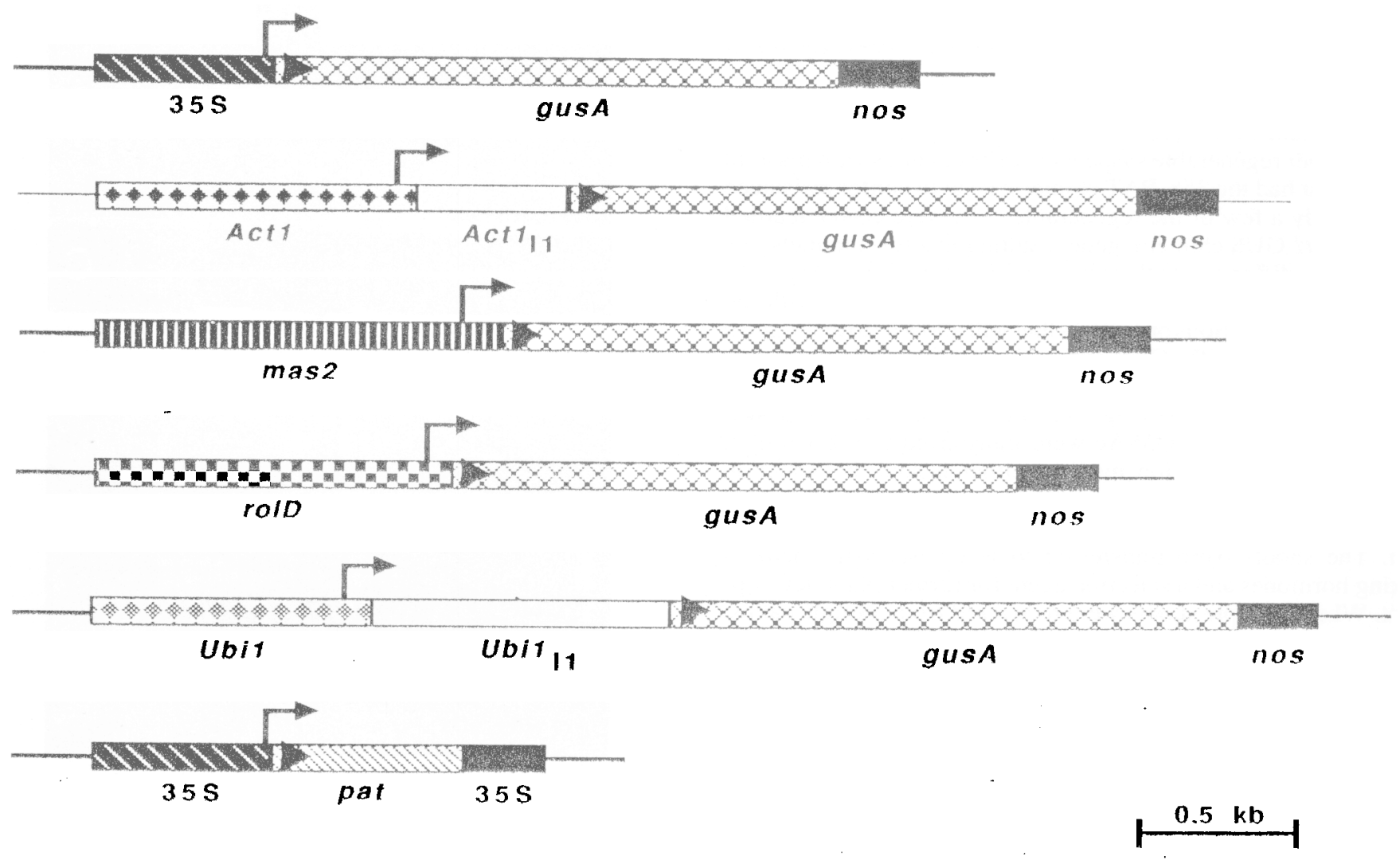

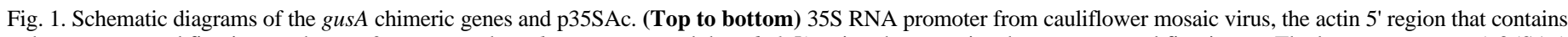

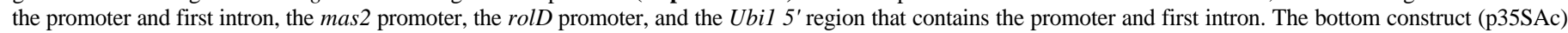
is the PAT gene under control of the CaMV $35 \mathrm{~S}$ promoter. 
orchid protocorms followed by the mas 2 promoter. Our results suggest that some nongraminaceous ornamental monocots should be treated more like dicots rather than monocots when issues regarding transgene expression are being addressed. It should be recognized that the relative efticiencies of the promoters in regenerated Gladiolus plants may be different from the values obtained in our transient assays, and this will be addressed when transgenic plants containing these gusA gene fusions are available for analysis.

Others (Russell et al., 1992; Vain et al., 1993) have reported that tobacco and maize suspension cells preconditioned in osmoticum before particle bombardment increased levels of GUS expression $\approx 3$-fold compared to cells not grown in osmoticum. The optimum concentration of osmoticum resulting in a 3.2-fold increase of GUS expression was 0.125 m for suspension cells of Gladiolus compared to $0.25 \mathrm{M}$ and $0.4 \mathrm{~m}$ for tobacco and maize suspension cells, respectively (data not shown).

Recovery of transgenic Gladiolus cells. The plasmid, pAct1F4, which contains an Act1- GUS chimeric gene, was co-bombarded with p35SAc DNA into nonregenerable Gladiolus cells. For selection, bombarded cells were moved to MS basal salts medium containing either PPT or bialaphos. After 4 weeks, healthy, yellow microcalli began to appear against a background of dead cells. The microcalli were subculture to PPT-containing medium for continued growth. When PPT-resistant Gladiolus cells were assayed for GUS activity (Fig. 2A), $\approx 70 \%$ of the transformants that contained the PAT gene as determined by PCR analysis expressed detectable levels of GUS enzyme. This co-expression rate compares favorably with the rates observed in other plant transformation systems after co-bombardment with two plasmids. Suspension cells of 'Jenny Lee' expressed high levels of GUS (25 to 40 nmol MU/h per mg protein), which is comparable to the highest levels reported for other monocots (Hagio et al., 1991; Lyznik et al., 1989).

Recovery of transgenic Gladiolus plants. Stably transformed Gladiolus plants were recovered following particle gun bombardment of either regenerable suspension cells or callus with plasmid p35SAc that had the 35 S-PAT chimeric gene to confer resistance to PPT. Only a few of the regenerable cells were co-bombarded with the Act1 GUS chimeric gene resulting in a few plantlets just beginning to differentiate that showed GUS expression (Fig. 2B). Currently, we are in the pocess of transforming plants with the GUS gene under various promoters that will allow us to distinguish between tissue-specific GUS expression and possible chimeras. These results will be reported once these plants are available. To recover transgenic plants (Fig. 2C), PPT-resistant calli that had been bombarded with p35SAc were transferred to regeneration medium. The regeneration medium either lacked the selection agent or contained a lower concentration $\left(0.5\right.$ or $3.0 \mathrm{mg} \cdot$ liter $^{-1}$ PPT). After 3 to 4 weeks, green shoots appeared on some of the calli. The shoots were transferred to MS basal salts medium lacking hormones and a selection agent for further plant development. When multiple shoots were recovered from a single callus, PCR analysis performed on individual shoots sampled from the single callus verified that at least $90 \%$ of the shoots derived from that callus were transgenic. Twenty-five of the transgenic plants were grown for 2 months on MS medium supplemented with 4.0 $\mathrm{mg} \cdot$ liter ${ }^{-1} \mathrm{PPT}$ compared to the nontransformed plants that died after only 1 week on this concentration of PPT, indicating expression of phosphinothricin acetyltransferase by the transgenic plants.

A total of 33 plates of regenerable callus and 18 plates of regenerable suspension cells was bombarded with the PAT gene, resulting in 110 transformed plants recovered. The 110 transformed plants contain the PAT gene as indicated by PCR analysis.
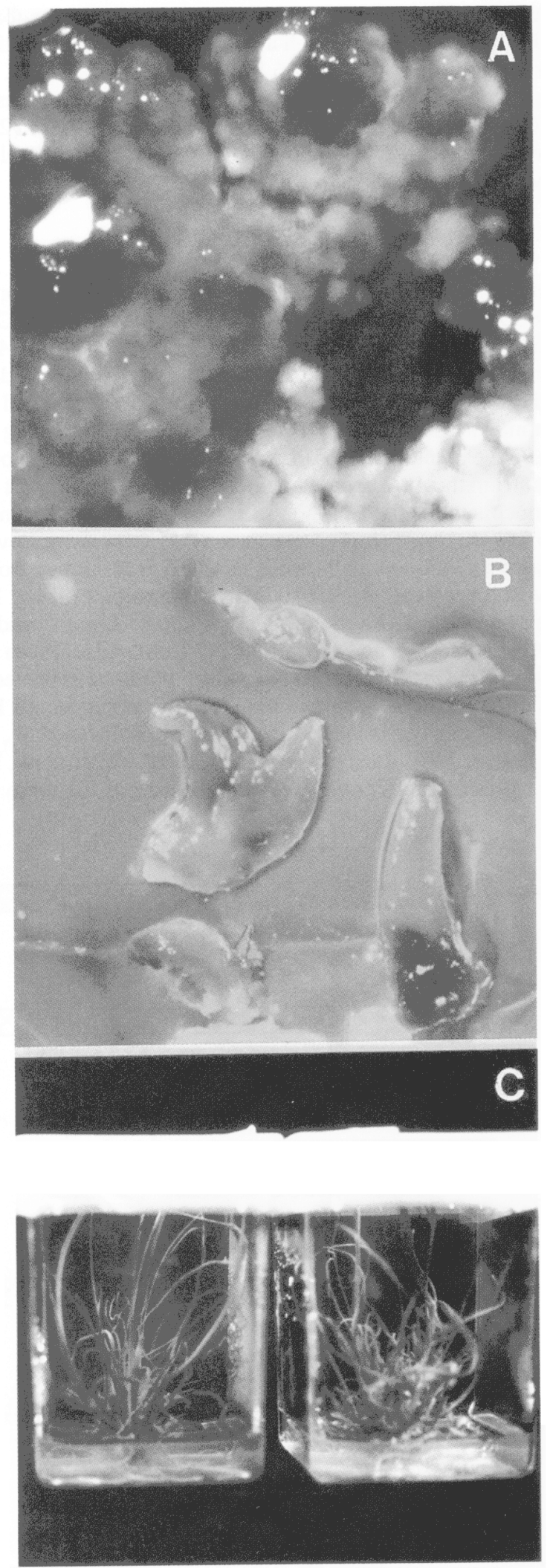

Fig. 2. (A) 'Jenny Lee' callus showing GUS expression after incubation with 5bromo-4-chloro-3-indolyl-3- $\beta$-glucuronic acid (X-gluc). The callus had been selected on MS basal salts medium supplemented with $0.5 \mathrm{mg} \cdot \operatorname{liter}^{-1} 2,4-\mathrm{D}$ and $6 \mathrm{mg} \cdot$ liter $^{-1}$ PPT. (B) Plantlets just beginning to develop and stained to show GUS expression. (C) Transgenic plants of Gladiolus 'Jenny Lee' grown in vitro on MS basal salts medium without hormones. 


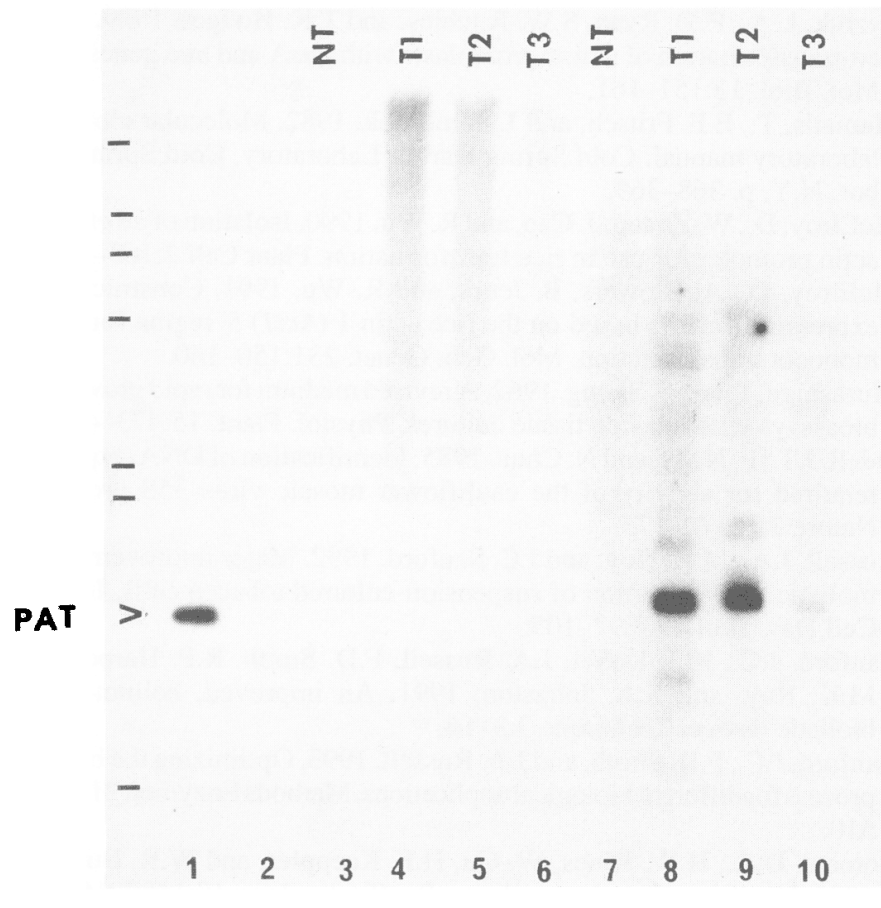

Fig. 3. DNA blot of genomic DNA isolated from leaves of Gladiolus grown in vitro probed with p35SAc digested with Sal L Each lane contains $10 \mu \mathrm{g}$ DNA. Lane 1: p35SAc digested with EcoRI, which released $50 \mathrm{pg}$ of a $1.34 \mathrm{~kb}$ insert. Lane 2: $4 \mu \mathrm{g}$ lambda DNA digested with HindIII. Lanes 3-6 are uncut genomic DNA for nontransformed (NT) Gladiolus or three transformants (T1-3). Lanes 7-10 are genomic DNA digested with EcoRI for NT or three transformants (T1-3). Size markers shown on the left represent 23.1, 9.4, 6.7, 4.4, 2.3, 2.0, and $0.56 \mathrm{~kb}$, from top to bottom.

Additional putative transformed plants could have been recovered from the selection medium; however, we did not wish to maintain more plants. Southern hybridizations have been performed on nine of the transformants, and two were found to be duplicates. Currently, the other transformed plants are being analyzed by DNA blot analysis so that it can be determined whether they are independent transformants.

DNA gel blot analysis indicated stable incorporation of the PAT gene into the Gladiolus genome (Fig. 3). When the transgenic plants reached sufficient size, genomic DNA was isolated for DNA gel blot analysis. Genomic DNA samples were digested with EcoRI and probed-with radiolabeled PAT DNA. The expected 1.3 $\mathrm{kb}$ EcoRI fragment was observed in lanes containing DNA from the transgenic plants. T3 contains one or only a few copies of the PAT gene compared to $\mathrm{T} 1$ and T2. PCR analysis clearly verified the presence of the PAT gene in T3 (data not shown). The amount of DNA loaded onto the gel was identical as that used for T1 and $\mathrm{T} 2$, so the difference in signal of the diagnostic band can be attributed to a difference in copy number. The particle gun typically results in a variable number of copies inserted into the plant genome (Gordon-Kamm et al., 1990; Somers et al., 1992; Weeks et al., 1993). No $1.3 \mathrm{~kb}$ signal was evident in the lane containing genomic DNA isolated from untransformed plants. There was a difference in the minor bands for $\mathrm{T} 1$ and $\mathrm{T} 2$, indicating a different pattern of gene rearrangement for each transformant. The particle gun frequently results in gene rearragements (Gordon-Kamm et al., 1990; Somers et al., 1992; Weeks et al., 1993). Additional evidence that $\mathrm{T} 1$ and $\mathrm{T} 2$ represent independent transformants was provided following digestion of their genomic DNA with PstI that digests once within the transgene (Fig. 4)

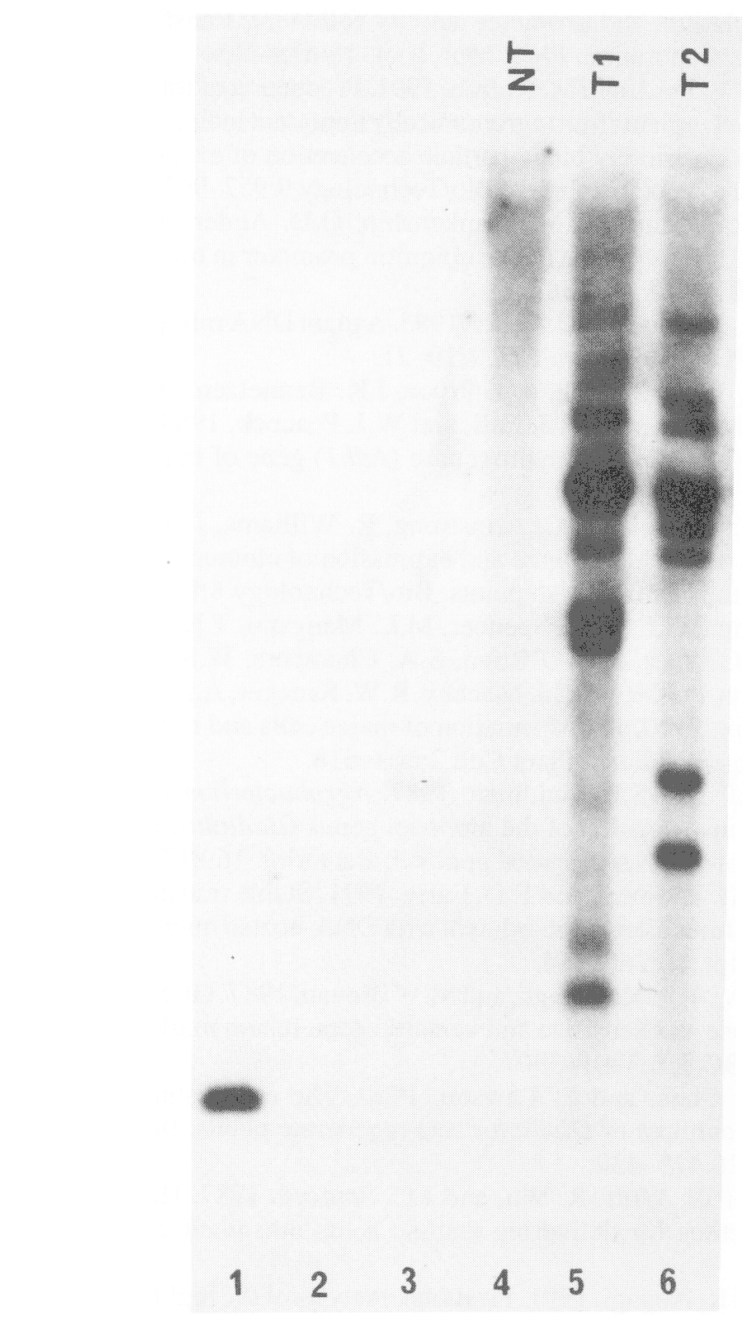

Fig. 4. DNA blot of genomic DNA isolated from leaves of Gladiolus grown in vitro probed with p35SAc digested with SalI. Each lane contains $10 \mu \mathrm{g}$ DNA. Lane 1: p35SAc digested with SalI, which released $50 \mathrm{pg}$ of a $559 \mathrm{bp}$ insert. Lane $2: 4 \mu \mathrm{g}$ lambda DNA digested with HindIII. Lane 3:2 $\mu \mathrm{g} 1 \mathrm{~kb}$ ladder. Lane 4 genomic DNA digested with PstI from NT plant. Lanes 5 and 6: Genomic DNA digested with PstI from T1 and T2, respectively.

The introduced plasmid DNA was determined to have integrated into the genome (Fig. 3). Undigested genomic DNA was electrophoresed through agarose and probed with the PAT gene. The PAT-hybridizing signal was located in the region of the gel that contained high molecular weight DNA consistent with integration of the plasmid into the genome.

This biolistic transformation protocol resulted in the recovery of large numbers of transgenic Gladiolus plants transformed with the PAT and gusA genes. More than 100 transformed plants were obtained from both bombarded callus and suspension cells of two commercial y available Gladiolus 'Jenny Lee' and 'Peter Pears'. We are now positioned to introduce transgenes that can confer horticulturally important traits into commercial cultivars of Gladiolus.

\section{Literature Cited}

Bower, R. and R.G. Birch. 1992. Transgenic sugarcane plants via microprojectile bombardment. Plant J. 2:409-416.

Christensen, A. H., R.A. Sharrock, and P.H. Quail. 1992. Maize polyubiquitin genes: Structure, thermal perturbation of expression and 
transcript splicing, and promoter activity following transfer to protoplasts by electroporation. Plant Mol. Biol. 18:675-689.

Christou, P., T.L. Ford, and M. Kofron. 1991. Production of transgenic rice (Oryza sativa L.) plants from agronomically important indica and japonica varieties via electric discharge particle acceleration of exogenous DNA into immature zygotic embryos. Biotechnology 9:957-962.

Cornejo, M.J., D. Luth, K.M. Blankenship, O.D. Anderson, and A.E. Blechl. 1993. Activity of a maize ubiquitin promoter in transgenic rice. Plant Mol. Biol. 23:567-581.

Dellaporta, S., J. Wood, and J. Hicks. 1983. A plant DNA minipreparation version II. Plant Mol. Biol. Rpt. 1:19-21.

Dennis, E. S., W.L. Gerlach, A.J. Pryor, J.K. Bennetzen, A. Inglis, D. Llewellyn, M.M. Sachs, R.J. Ferl, and W.J. Peacock. 1984. Molecular analysis of the alcohol dehydrogenase (Adh1) gene of maize. Nucleic Acids. Res. 12:3983-4000.

Fromm, M. E., F. Morrish, C. Armstrong, R. Williams, J. Thomas, and T.M. Klein. 1990. Inheritance and expression of chimeric genes in the progeny of transgenic maize plants. Biotechnology 8:833-839.

Gordon-Kamm, W.J., T.M. Spencer, M.L. Mangano, T.R. Adams, R.J. Dairies, W.G. Start, J.V. O'Brien, S.A. Chambers, W.R. Adams, Jr., N.G. Willetts, R.B. Rice, C.J. Mackey, R.W. Krueger, A.P. Kausch, and P.G. Lemaux. 1990. Transformation of maize cells and regeneration of fertile transgenic plants. Plant Cell 2:603-618.

Graves, A.C.F. and S.L. Goldman. 1987. Agrobacterium tumefaciensmediated transformation of the monocot genus Gladiolus: detection of expression of T-DNA-encoded genes. J. Bacteriol. 169:1745-1746.

Hagio, T., A.D. Blowers, and E.D. Earle. 1991. Stable transformation of sorghum cultures after bombardment with DNA-coated microprojectiles. Plant Cell Rpt. 10260-264.

Jefferson, R. A., T.A. Kavanagh, and M.W. Bevan. 1987. GUS-fusions: $\beta-$ glucuronidase as a sensitive and versatile gene fusion marker in higher plants. EMBO J. 6:3901-3907.

Kamo, K., J. Chen, and R. Lawson. 1990. The establishment of cell suspension cultures of Gladiolus that regenerate plants. In Vitro Cell. Dev. Biol. 26:425-430.

Klein, T.M., E.D. Wolf, R. Wu, and J.C. Sanford. 1987. High velocity microprojectiles for delivering nucleic acids into plant cells. Nature 327:70-73.

Leach, R. and K. Aoyagi. 1991. Promoter analysis of the highly expressed rolC and rolD root-inducing genes of Agrobacterium rhizogenes: Enhancer and tissue-specific DNA determinants are dissociated. Plant Sci. 79:69-76

Logan, A.E. and F.W. Zettler. 1985. Rapid in vitro propagation of virusindexed Gladioli. Acta Hort. 164: 169-180.
Lyznik, L.A., R.D. Ryan, S.W. Ritchies, and T.K. Hodges. 1989. Stable co-transformation of maize protoplasts with gusA and neo genes. Plant Mol. Biol. 13:151-161.

Maniatis, T., E.F. Fritsch, and J. Sambrook. 1982. Molecular cloning A laboratory manual. Cold Spring Harbor Laboratory, Cold Spring Harbor, N.Y. p. 368-369.

McElroy, D., W. Zhang, J. Cao, and R. Wu. 1990. Isolation of an efficient actin promoter for use in rice transformation. Plant Cell 2: 163-171.

McElroy, D., A. Blowers, B. Jenes, and R. Wu. 1991. Construction of expression vectors based on the rice actin 1 (Act1) 5 ' region for use in monocot transformation. Mol. Gen. Genet. 231:150-160.

Murashige, T. and F. Skoog. 1962. A revised medium for rapid growth and bioassays with tobacco tissue cultures. Physiol. Plant. 15:473-497.

Odell, J.T., F. Nagy, and N. Chua. 1985. Identification of DNA sequences required for activity of the cauliflower mosaic virus 35S promoter. Nature 313:170-173.

Russell, J.A., M.K. Roy, and J.C. Sanford. 1992. Major improvements in biolistic transformation of suspension-cultured tobacco cells. In Vitro Cell Dev. Biol. 28P:97-105.

Sanford, J.C., M.J. DeVit, J.A. Russell, F.D. Smith, R.P. Harpending, M.K. Roy, and S.A. Johnston, 1991. An improved, helium-driven biolistic device. Technique 3:3-16.

Sanford, J. C., F.D. Smith, and J.A. Russell, 1993. Optimizing the biolistic process for different biological applications. Methods Enzymol. 217:483510 .

Somers, D.A., H.W. Rines, W. Gu, H.F. Kaeppler, and W.R. Bushnell. 1992. Fertile, transgenic oat plants. Biotechnology 10: 1589-1594.

U.S. Department of Agriculture. 1994. Fresh fruits, vegetables and ornamental crops. No. WS-04-94.

Vain, P., M.D. McMullen, and J.J. Finer. 1993. Osmotic treatment enhances particle bombardment-mediated transient and stable transformation of maize. Plant Cell Rpt. 12:84-88.

Vasil, V., A.M. Casino, M.E. Fromm, and I.K. Vasil. 1992. Herbicide resistant fertile transgenic wheat plants obtained by microprojectile bombardment of regenerable embryogenic callus. Biotechnology 10:667-674.

Velten, J., L. Velten, R. Hain, and J. Schell. 1984. Isolation of a dual plant promoter fragment from the Ti plasmid of Agrobacterium tumefaciens. EMBO J. 3:2723-2730.

Weeks, J.T., O.D. Anderson, and A.E. Blechl. 1993. Rapid production of multiple independent lines of fertile transgenic wheat (Triticum aestivum). Plant Physiol. 102: 1077-1084.

Zhang, W., D. McElroy, and R. Wu. 1991. Analysis of rice Act1 5' region activity in transgenic rice plants. Plant Cell 3:11 55-1 165. 